\title{
Foliar application of systemic acquired resistance (SAR) inducers for controlling grape anthracnose caused by Sphaceloma ampelinum de Bary in Thailand
}

\author{
Inchaya Prakongkha ${ }^{1}$, Mathukorn Sompong ${ }^{1}$, Sopone Wongkaew ${ }^{1}$, Dusit Athinuwat ${ }^{3}$ and \\ Natthiya Buensanteai ${ }^{1,2 *}$
}

${ }^{1}$ School of Crop Production Technology, Institute of Agriculture Technology, Suranaree University of Technology, Nakhon Ratchasima, 30000 Thailand.

${ }^{2}$ Unité Mixte de Recherche Eco and Sols (Ecologie fonctionnelle and biogéochimie des Sols and des Agroécosystèmes), UMR 1222 INRA-IRD-SupAgro Montpellier, Place Pierre Viala, 34060 Montpellier cedex 01, France.

${ }^{3}$ Major of Organic Farming Management, Faculty of Science and Technology, Thammasat University, Pathumthani, 12121, Thailand.

Accepted 25 February, 2013

\begin{abstract}
Chitosan and benzo-(1,2,3)-thiadiazole-7-carbothioic acid S-methyl ester (BTH) are active-elicitors that induce protection in grapevine against several diseases. In this study, treatment of grapevine with chitosan and BTH provided protection to anthracnose, caused by Sphaceloma ampelinum. Chitosan and BTH treatment also increased chitinase, B-1,3-glucanase and peroxidase activities levels in leaves over non-treated plants. Differential accumulation of these traits was more rapid and pronounced when chitosan and BTH treated plants were infected with S. ampelinum; this pattern indicating priming. The induced resistance by chitosan and BTH was also associated with increased production of salicylic acid (SA) in grapevine leaves, suggesting that SA-dependent signaling pathways are systemically triggered by these compounds. Apart from proteins with defense-related function, most of the proteins induced by chitosan and BTH were involved in defense mechanism, reflecting the strong direct positive effect that chitosan and BTH has on grapevine tolerance to anthracnose disease infection.
\end{abstract}

Key words: Anthracnose, grapevine, induce resistance, systemic acquired resistance (SAR) biochemical markers, Sphaceloma ampelinum.

\section{INTRODUCTION}

Grape anthracnose caused by Spaceloma ampelinum (telemorph: Elisino ampelina) is widely known in Thailand as scab (Pienpuck et al., 1993; Sompong et al., 2012). It is considered one of the most serious diseases of grapes in Thailand because of the favorable warm and wet climate. The fungus causes characteristic necrotic spots on leaves, petioles, tendrils, young shoots and berries.

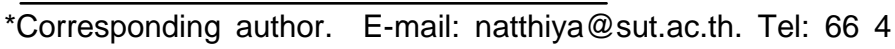
422 4204. Fax: 6644224351.
Severe infection can cause a range of symptoms from shot holes, shoot die-back, deformed leaves, blemished fruits, premature fruit drop, and vine decline (Poolsawat et al., 2008; Poolsawat et al., 2010). The disease is particularly severe during the rainy season starting from early May to late October when young berries start to develop. The disease is wide spread in all growing regions on most grape cultivars but table grapes are the most susceptible ones (Pienpuck et al., 1993; Poolsawat et al., 2008; Sompong et al., 2012). Chemical control by protective fungicides such as, dithiocarbamates alternated with systemic one, such as, benomyl or triazoles 
has been recommended but their application is often ineffective due to continuous rainfall during the rainy season. The sprayed chemicals are mostly washed off soon after the application and spray timing is difficult to be ascertained because of unexpected rainfall. Apart from such limitations, the target fungus can build up resistance to chemicals regularly used and the chemicals always leave their residues in the berries and environment making the application less desirable. Retractable plastic roofing over the vines has been proved effective in reducing the disease severity and making chemical control more efficient (Wongkaew and Boonkerd, 2010), but it is considerably costly and may be cost-effective only on the high-price table grapes.

In recent years, resistance inducers have been extensively evaluated as a means to control plant diseases based on the systemic acquired resistance (SAR) concept (Sticher et al., 1997; Vallad and Goodman, 2004). SAR is part of the plant innate defense system that could confer long-lasting protection against a broad range of pathogens (Jetiyanon et al., 1997; Kuć and Richmond, 1997; Eikemo et al., 2003; Durrant and Dong, 2004; Iriti et al., 2004; Godard et al., 2009; Verhagen et al., 2010; Verhagen et al., 2011; Graham and Myers, 2011; Iriti et al., 2011; Perazzoli et al., 2011; Hatem et al., 2012). Once resistance is induced, the plant acquires enhanced defensive capacity against subsequent infection by pathogens. SAR requires salicylic acid (SA) as a signal molecule and is associated with production and accumulation of pathogenesisrelated (PR) proteins (Malamy et al., 1990; Vidal et al., 1997; Buensanteai et al., 2009; Mandal et al., 2009). The inducers could be both synthetic and natural compounds. Among the synthetic inducers, benzo $(1,2,3)$-thiadiazole7-carbothionic acid S-methyl ester or acibenzolar-Smethyl (ASM), a functional homolog of SA has been extensively evaluated against grapevine fungal diseases (Perazzoli et al., 2008; Slaughter et al., 2008; EschenLippold et al., 2010). Its application has been registered on many crops and in many countries (Friedrich et al., 1996; Godard et al., 1999; Vallad and Goodman, 2004; Eschen-Lippld et al, 2010; Graham and Myers, 2011). For natural compounds, chitosan biopolymers produced by deacetylation of chitin from crustracean exoskeleton, have been tested to be most effective in stimulating plant growth and building up resistance to many diseases (Sathiyabama and Balabramaian, 1995; Awadalla and Mahmoud, 2005; Manjunatha et al., 2009; El Hadrami et al, 2010). Mechanisms of chitosan-induced resistance have been recently revised and include rising of cytosolic $\mathrm{H}^{+}$and $\mathrm{Ca}^{2+}$ activation of MAP-kinases, callose deposition, oxidative burst, hypersensitive response $(\mathrm{HR})$, synthesis of abscisic acid (ABA), jasmonate, phytoalexins and pathogenesis related (PR) proteins (Iriti and Faoro, 2009).

Even though there have been proves of effectiveness in using resistance inducers for controlling crop diseases, none of them have been tried on grape anthracnose.
Chitosan has been widely used in Thailand but mostly as a plant growth stimulator and its potential as a disease resistance inducer has never been evaluate under the Thailand growing condition (Sompong et al., 2012). The aim of this research was to evaluate the effectiveness of these two different resistance inducers in controlling the grape anthracnose disease and to investigate their mode of action by monitoring the production of SAR relating chemicals after their application.

\section{MATERIALS AND METHODS}

\section{Experimental condition and treatments}

The experiment was conducted in a green house at Suranaree University of Technology, Nakorn Ratchasima, Thailand during August to October, 2011. The average temperature in the greenhouse was $30 \pm 2$ and $26 \pm 2^{\circ} \mathrm{C}$ at day time and night time, respectively. Two month old cuttings of Black Queen grape, the most susceptible cultivar to anthracnose (Sompong et al., 2012) was used as experimental plants, and the single-spore-isolated GB4, the most severe isolate of $S$. ampelinum (data not shown) was used as the pathogen. The experiment was arranged in a randomized complete block design with nine treatments replicated four times. The treatments consisted of foliar sprays of chitosan (Fluka chitosan from crab shell; low molecular weight) in $4 \% \mathrm{HCl}$ and the dilute in deionized water at 1000,2500 and $5000 \mathrm{mgl}^{-1}$, ASM (Bion 50WG; 50\% a.i.; Syngenta Crop Protection) at 50, 100, and $200 \mathrm{mg} \mathrm{L}^{-1}$. All these inducers were sprayed onto the middle leaf of each plant until run off. The untreated control plants received only a deionized water spray. The treatments were similarly given to four sets of plants to correspond with the three sampling times of SAR chemical analyses that is, immediately after spraying that is, seven days and 15 days after spraying. The 4th set of plants was kept for disease scoring. At 10 days after the induction, the treated and control plants were inoculated with a spore suspension of $S$. ampelinum GB4 $\left(4 \times 10^{6}\right.$ spores $\left.\mathrm{ml}^{-1}\right)$. The inoculation was done by spraying the spore suspension on to all leaves of each plant until run off.

\section{SAR chemical analyses}

At 0, 7 and 15 days after inducer application, the treated, the lower, and the upper leaves were collected from each treated and watertreated plants for SAR relating chemical analyses. After being detached, each leaf was cut into two halves and the three halved leaves were pooled and treated as 1 sample. Subsequently, they were cut to smaller pieces of about 1 square $\mathrm{cm}$ and thoroughly mixed before analysis samples were taken. Leaf tissues of the first half was analyzed for SA, while the second half was assayed for chitinase, B-1,3-glucanase, and polyphenol oxidase (PPO) activities.

\section{SA analysis}

The method as described by Raskin et al. (1989) was used for the analysis. Pooled leaf tissue $(0.5 \mathrm{~g})$ from each replication were randomly sampled, frozen with liquid nitrogen and macerated in a cold mortar with $1 \mathrm{ml}$ of extraction solution (90:9:1 volume of absolute methanol, glacial acetic acid, and distillate water). The extract was subsequently centrifuged at $12000 \mathrm{~g}$ and $4^{\circ} \mathrm{C}$ for 15 min and the supernatant was collected for the analysis. To determine the SA content, $500 \mu \mathrm{l}$ of the supernatant was mixed with 
an equal volume of $0.02 \mathrm{M}$ ferric ammonium sulfate, incubated at $30^{\circ} \mathrm{C}$ for $5 \mathrm{~min}$ and the absorbance at $530 \mathrm{~nm}$ was read by a spectrophotometer. The read absorbance was subsequently compared to those of the reference standard to obtain the actual amount of SA in the sample.

\section{PR proteins and defense enzyme analyses}

Total proteins from the second set of half leaves were extracted by the method as described by Buensanteai et al. (2009). The leaves were similarly cut and pooled as for SA analysis. Subsequently, 0.5 $\mathrm{g}$ of the frozen tissues from each replication were macerated in a cold mortar with $1 \mathrm{ml}$ of extraction buffer $(0.1 \mathrm{M}$ Tris $-\mathrm{HCl} \mathrm{pH} 7.0$, $0.1 \mathrm{M} \mathrm{KCl}, 1 \mathrm{mM}$ phenylmethylsulfonyl fluoride, $10 \mathrm{ml} / \mathrm{L}$ Triton $\mathrm{X} 100$, and $3 \%$ polyvinylpyrrolidone). After being thoroughly vortexed, the extract was centrifuged at $12,000 \mathrm{~g}$ and $4^{\circ} \mathrm{C}$ for $30 \mathrm{~min}$ and the supernatant was collected for protein analysis using the standard Bradford protein assay (Bradford, 1976). After the assay, the protein homogenate from each replication was divided into three equal portions for enzyme activity determination.

\section{Determination of chitinase activity}

$400 \mu \mathrm{l}$ of the protein homogenate was mixed with an equal volume of $0.1 \%(\mathrm{w} / \mathrm{v})$ colloidal chitin in $0.05 \mathrm{M}$ sodium acetate buffer $\mathrm{pH} 5.0$ and incubated for $2 \mathrm{~h}$ at $37^{\circ} \mathrm{C}$. The $\mathrm{N}$-acetyl glucosamine (GlcNAc) produced from the reaction was determined by spectrophotometric reading at $585 \mathrm{~nm}$.

\section{Determination of B-1,3-glucanase activity}

$62.5 \mu \mathrm{l}$ of the protein homogenate was mixed with an equal volume of $4 \%(\mathrm{w} / \mathrm{v})$ laminarin in $0.05 \mathrm{M}$ sodium acetate buffer $\mathrm{pH} 5.0$ and incubated at $40^{\circ} \mathrm{C}$ for $10 \mathrm{~min}$. (Pan et al., 1991). The reaction was stopped by adding in $375 \mu \mathrm{l}$ of dinitrosalicylic acid and dipping in boiling water for $5 \mathrm{~min}$. Glucose produced from the reaction was determined by reading the absorbance at $500 \mathrm{~nm}$ followed the method described by Pan et al. (1991) and Buensanteai et al. (2009).

\section{Determination of PPO activity}

Four dilutions of the homogenate of each replication were assayed for PPO activity using the procedure described by Thipayapong (1995). The dilutions were made by mixing the homogenate with the protein extraction buffer at the ratios 10:30, 20:20,30:10, and 40:0 $\mu$ l. Subsequently, $5 \mu \mathrm{l}$ of catalase $\left(84\right.$ unit $\left.\mu^{-1}\right)$ was added to each dilution and incubated for 15 min before the absorbance at $412 \mathrm{~nm}$ was measured using a spectrophotometer. After the measurement, $1 \mathrm{ml}$ of substrate solution (96 $\mu \mathrm{M}$ 2-nitro-5-thiobenzoic acid and $1.77 \mathrm{mM}$ 4-methylcathechol in $0.1 \mathrm{M}$ Tris $\mathrm{HCl} \mathrm{pH}$ 7.0) was added into the mixture of each dilution and the quinone produced from the reaction was monitored by measuring the absorbance at $412 \mathrm{~nm}$ every $5 \mathrm{~s}$ for $30 \mathrm{~min}$. Conversion of the decreased absorbance into the PPO activity was done by linear regression as described by Thipayapong (1995).

\section{Disease severity scoring}

After fungal inoculation, plants in the four sets were observed for symptom expression and the first day when symptoms appeared in each treatment was recorded. Disease severity in each treatment was compared at five days after inoculation when plants in all treat- ments had shown the symptoms, which was at 15 days after the inducer application. Disease scoring 1 to 5 of Poolsawat et al. (2010) was used for the assessment where $1=$ no symptom, $2=$ less than $25 \%$ of affected leaf area, $3=26-50 \%$ of affected leaf area, $4=51-75 \%$ of affected leaf area, and $5=$ more than $75 \%$ of affected leaf area.

\section{Statistical analysis}

Data for SA content and PR proteins and defense enzyme of the induced plants collected at three different dates, and disease scores assessed at 15 days after the induction were subjected to a one-way analysis of variance (ANOVA) separately using version 14 of SPSS program. The New Duncan's Multiple Range Test (DMRT) was used to separate the treatment means at $P \leq 0.05$.

\section{RESULTS}

\section{Grapevine anthracnose disease severity assessment}

In this experiment using grapevine cultivar Black Queens, foliar treatment with chitosan and BTH reduced the severity of anthracnose in the grapevine foliage, confirming that induction of systemic resistance had occurred. The results indicate that treatment with chitosan and BTH reduced the severity of anthracnose in leave by more 75 and $60 \%$, respectively when compared to the sterile distilled water as negative control (Table 1, Figures 1 and 2).

\section{SAR biochemical analyses}

In this study, chitosan and BTH were evaluated for their ability to induce defense responses and related chemicals to protect grapevine from $S$. ampelinum infection. Grapevine treatment with chitosan and BTH triggered increased accumulation of biochemical markers associated with induced resistance mainly after $S$. ampelinum inoculation.

\section{Salicylic acid analysis}

Our results indicate that in grapevine plants of cultivar Black Queens treated with chitosan and BTH, salicylic acid level increased significantly seven days after treatment and much more seven days after challenge inoculation, reaching the maximum concentration of 13.08, and $12.15 \mathrm{\mu g} \mathrm{g}^{-1}$ fresh weights for chitosan and BTH (Table 2). By contrast, SA accumulation in nontreated, but pathogen-inoculated grapevine, was considerably lower $\left(2.90 \mathrm{\mu g} \mathrm{g}^{-1}\right.$ fresh weight).

\section{PR proteins and defense enzyme analysis determination of chitinase activity}

Our results indicate that in grapevine plants of cultivar Black Queens treated with chitosan and BTH, chitinase 
Table 1. Effect of foliar treatment with chitosan and BTH on severity of anthracnose disease in grapevine cultivar Black Queens.

\begin{tabular}{lcc}
\hline \multirow{2}{*}{ Treatment } & \multicolumn{2}{c}{ Disease severity $^{1 /}$} \\
\cline { 2 - 3 } & Disease score $^{2 /}$ & Disease symptom (Days after inoculation) \\
\hline CHN 1,000 ppm & $2.33 \mathrm{ab}^{3 /}$ & 4 \\
CHN 2,500 ppm & $2.33 \mathrm{ab}$ & 4 \\
CHN5,000 ppm & $1.33 \mathrm{a}$ & 5 \\
BTH 50 ppm & $2.33 \mathrm{ab}$ & 5 \\
BTH 100 ppm & $2.33 \mathrm{ab}$ & 4 \\
BTH 200 ppm & $3.00 \mathrm{~b}$ & 5 \\
Control & $4.89 \mathrm{c}$ & 2 \\
F-test & $* *$ & \\
CV(\%) & 17.89 & \\
\hline
\end{tabular}

${ }^{1 / G r a p e v i n e ~ l e a v e s ~ w e r e ~ c h a l l e n g e d ~ w i t h ~} S$. ampelinum strain GB4 or sterile distilled water 7 days after foliar treatment with chitosan and $\mathrm{BTH} ;{ }^{2 /}$ The disease score were including: 1 score $=$ leaf area necrosis between $0-6 \% ; 2$ score = leaf area necrosis less than $25 \% ; 3$ score = leaf area necrosis between $26-50 \%$; 4 score = leaf area necrosis between $51-75 \%$; 5 score = leaf area necrosis over $75 \%$ of all leaf area; ${ }^{3 /}$ disease severity was evaluated seven days after challenging with $S$. ampelinum strain GB4 or sterile distilled water. Each value represents a mean of three replicate plants with two leave per plant. Mean in the column followed by the same letter are not significantly different according to the LSD test $(\alpha=0.05)$.
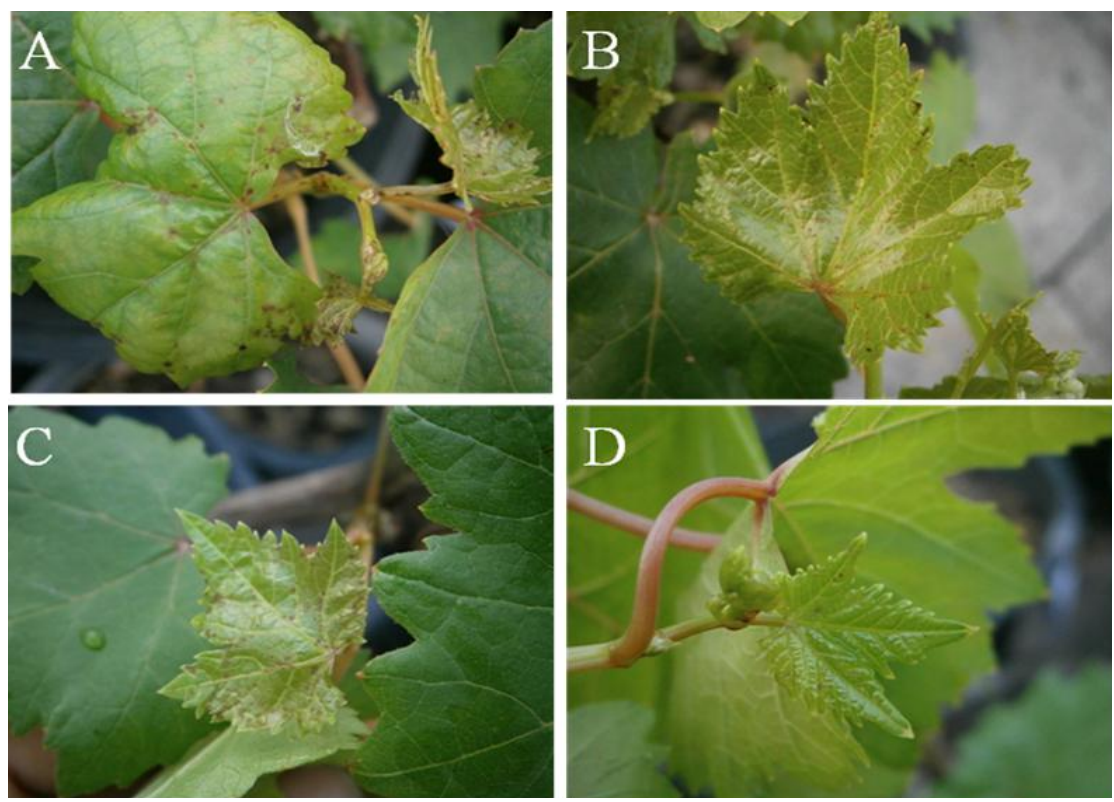

Figure 1. Anthracnose disease symptoms in leaves of grapevine cultivars Black Queens treated with water (A) or with chitosan at 1,000 ppm (B) 2,500 ppm (C) and 5,000 ppm (D).

activity level increased significantly 7 days after treatment and much more seven days after challenge inoculation with $S$. ampelinum, reaching the maximum concentration of 10.765 and 0.755 unit $\mathrm{mg}^{-1}$ protein respectively for chitosan and BTH (Table 3). By contrast, chitinase activity in non-treated, but pathogen-inoculated grapevine, was considerably lower $\left(0.303\right.$ unit $\mathrm{mg}^{-1}$ protein).

\section{Determination of B-1,3-glucanase activity}

Our results indicate that in grapevine plants of cultivar Black Queens treated with chitosan and BTH, B-1,3 glucanase activity increased significantly 7 days after treatment and much more 7 days after challenge inoculation, reaching the maximum concentration of 0.843 , and 0.790 unit $\mathrm{mg}^{-1}$ protein respectively for 

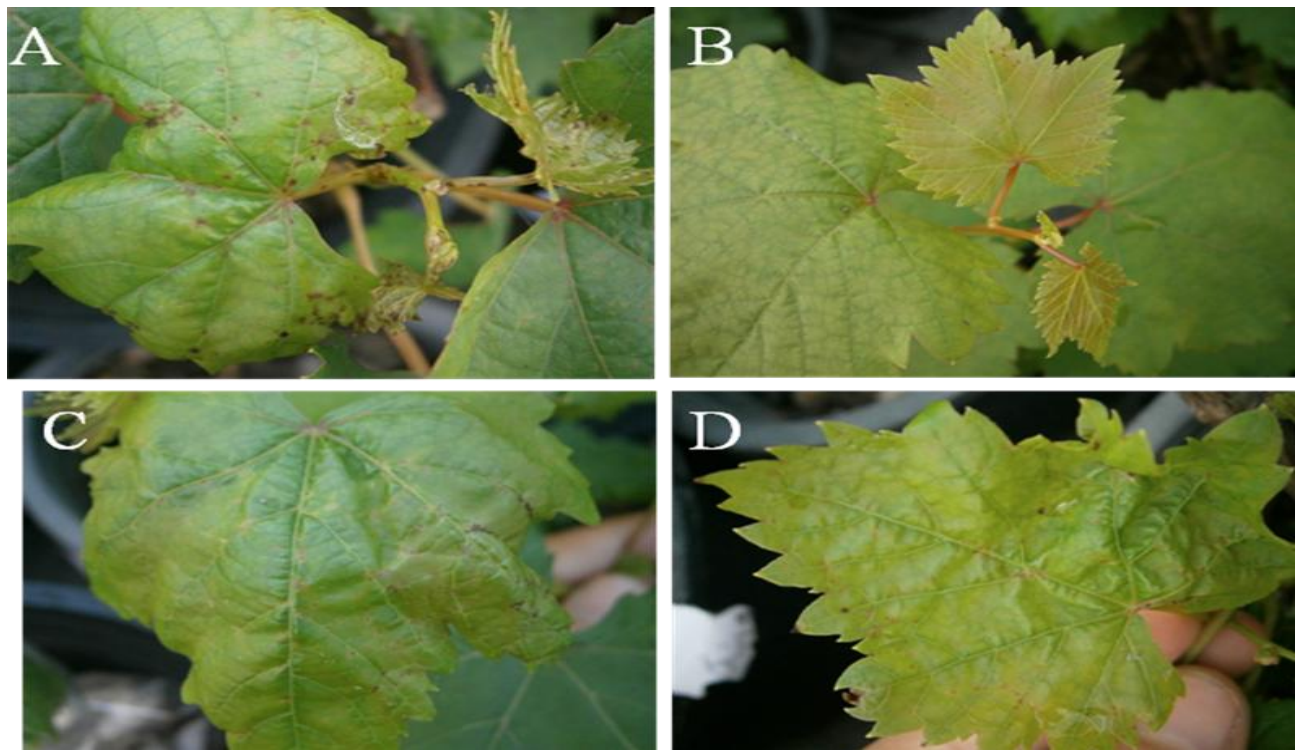

Figure 2. Anthracnose disease symptoms in leaves of grapevine cultivars Black Queens treated with water (A) or with BTH at 50 ppm (B) 100 ppm (C) and 200 ppm (D).

Table 2. Accumulation of salicylic acid in leaves of grapevine cultivars Black Queens with or without chitosan and BTH foliar treatments and after challenge inoculation with Sphaceloma ampelinum.

\begin{tabular}{lccc}
\hline \multirow{2}{*}{ Treatment } & \multicolumn{3}{c}{ Salicylic acid $\left(\boldsymbol{\mu g} \mathbf{g}^{-1} \text { fresh weight }\right)^{1 /}$} \\
\cline { 2 - 4 } & $\mathbf{0}$ & $\mathbf{7}$ days & $\mathbf{1 4}$ days \\
\hline CHN 1,000 ppm & $0.78^{\mathrm{b} 2 /}$ & $3.57^{\mathrm{e}}$ & $12.19^{\mathrm{b}}$ \\
CHN 2,500 ppm & $0.60^{\mathrm{a}}$ & $3.99^{\dagger}$ & $10.58^{\mathrm{b}}$ \\
CHN 5,000 ppm & $0.99^{\mathrm{c}}$ & $2.98^{\mathrm{d}}$ & $13.08^{\mathrm{b}}$ \\
BTH 50 ppm & $0.79^{\mathrm{b}}$ & $3.06^{\mathrm{ef}}$ & $10.85^{\mathrm{b}}$ \\
BTH 100 ppm & $1.04^{\mathrm{c}}$ & $3.83^{\mathrm{ef}}$ & $12.15^{\mathrm{b}}$ \\
BTH 200 ppm & $1.46^{\mathrm{e}}$ & $2.16^{\mathrm{c}}$ & $11.54^{\mathrm{b}}$ \\
Control & $1.21^{\mathrm{d}}$ & $0.19^{\mathrm{a}}$ & $2.90^{\mathrm{a}}$ \\
F-test & $* *$ & $* *$ & $* *$ \\
CV $(\%)$ & 8.63 & 12.87 & 18.17 \\
\hline
\end{tabular}

${ }^{1 / S a l i c y l i c ~ a c i d ~ a c c u m u l a t i o n ~ w a s ~ e v a l u a t e d ~ a t ~} 0$ and 7 after treatment with chitosan and BTH or sterile distilled water (control) and at 7 days after challenging with S. ampelinum strain GB4 (14 days after treatment) ${ }^{2 /}$ each value represents a mean of three replicate plants with two leaves per plant. Mean in the column followed by the same letter are not significantly different according to the LSD test $(\alpha=0.05)$

chitosan and BTH (Table 4). By contrast, ß-1,3glucanase activity in non-treated, but pathogeninoculated grapevine, was considerably lower (0.467 unit $\mathrm{mg}^{-1}$ protein).

\section{Determination of PPO activity}

Our results indicate that in grapevine plants of cultivar Black Queens treated with chitosan and BTH, PPO activity level increased significantly seven days after treatment and much more seven days after challenge inoculation, reaching the maximum concentration of 11.227 and $10.153 \mu \mathrm{mol}$ quinone formed $\mathrm{min}^{-1} \mathrm{mg}^{-1}$ protein for chitosan and BTH, respectively (Table 5 ).

In contrast, PPO activity in pathogen-inoculated plants having no chitosan and $\mathrm{BTH}$ treatment was considerably lower. Non- chitosan and BTH treated plants of cultivar Black Queens exhibited a similar temporal change in PPO activity as chitosan and BTH treated plants. In this cultivar, foliar treatment with chitosan and BTH without pathogen inoculation caused only a slight elevation in PPO activity levels compared to the respective sterile distilled water control. 
Table 3. Activity of chitinase in leaves of grapevine cultivars Black Queens with or without chitosan and BTH foliar treatment and after challenge inoculation with S. ampelinum.

\begin{tabular}{lccc}
\hline \multirow{2}{*}{ Treatment } & \multicolumn{3}{c}{${\text { Chitinase activity (unit } \mathbf{~ m}^{-1}}^{\text {p protein })^{\mathbf{1 /}}}$} \\
\cline { 2 - 4 } & $\mathbf{0}$ & $\mathbf{7}$ days & $\mathbf{1 4}$ days \\
\hline CHN 1,000 ppm & $0.133^{3 /}$ & $0.396 \mathrm{c}$ & $0.691 \mathrm{c}$ \\
CHN 2,500 ppm & 0.135 & $0.417 \mathrm{~cd}$ & $0.726 \mathrm{~cd}$ \\
CHN 5,000 ppm & 0.132 & $0.444 \mathrm{~cd}$ & $0.755 \mathrm{~cd}$ \\
BTH 50 ppm & 0.130 & $0.423 \mathrm{~cd}$ & $0.710 \mathrm{~cd}$ \\
BTH 100 ppm & 0.131 & $0.434 \mathrm{~cd}$ & $0.732 \mathrm{~cd}$ \\
BTH 200 ppm & 0.133 & $0.451 \mathrm{~d}$ & $0.765 \mathrm{~d}$ \\
Control & 0.135 & $0.242 \mathrm{a}$ & $0.303 \mathrm{a}$ \\
F-test & $\mathrm{ns}$ & $\star *$ & $* *$ \\
CV(\%) & 15.44 & 9.75 & 5.10 \\
\hline
\end{tabular}

${ }^{1 / C h i t i n a s e ~ a c t i v i t y ~ w a s ~ e v a l u a t e d ~ a t ~} 0$ and seven days after treatment with chitosan and BTH or sterile distilled water (control) and at seven days after challenging with $S$. ampelinum strain GB4 (14 days after treatment); ${ }^{2 /}$ Each value represents a mean of three replicate plants with two leave per plant. Mean in the column followed by the same letter are not significantly different according to the LSD test $(\alpha=0.05)$.

Table 4. Activity of B-1,3-glucanase in leaves of grapevine cultivars Black Queens with or without chitosan and BTH foliar treatment and after challenge inoculation with $S$. ampelinum.

\begin{tabular}{|c|c|c|c|}
\hline \multirow{2}{*}{ Treatment } & \multicolumn{3}{|c|}{$\beta-1,3$-glucanase activity (unit $\mathrm{mg}^{-1}$ protein) $^{1 /}$} \\
\hline & 0 & 7 days & 14 days \\
\hline CHN 1,000 ppm & $0.211^{\mathrm{b} 2 /}$ & $0.470^{d}$ & $0.690^{c}$ \\
\hline $\mathrm{CHN} 2,500 \mathrm{ppm}$ & $0.270^{\mathrm{cd}}$ & $0.493^{\text {de }}$ & $0.707^{\mathrm{C}}$ \\
\hline CHN 5,000 ppm & $0.223^{b}$ & $0.523^{\mathrm{de}}$ & $0.750^{\text {cd }}$ \\
\hline BTH 50 ppm & $0.312^{g}$ & $0.497^{\text {de }}$ & $0.747^{\mathrm{cd}}$ \\
\hline BTH 100 ppm & $0.282^{\text {de }}$ & $0.473^{d}$ & $0.790^{\text {cd }}$ \\
\hline BTH 200 ppm & $0.213^{b}$ & $0.501 d^{e}$ & $0.843^{\mathrm{cd}}$ \\
\hline Control & $0.195^{\mathrm{a}}$ & $0.303^{\mathrm{a}}$ & $0.467^{\mathrm{a}}$ \\
\hline F-test & ** & ** & ** \\
\hline CV(\%) & 19.14 & 11.02 & 4.65 \\
\hline
\end{tabular}

1/ B-1,3-glucanase activity was evaluated at 0 and 7 days after treatment with chitosan and BTH or sterile distilled water (control) and at 7 days after challenging with Sphaceloma ampelinum strain GB4 (14 days after treatment);

${ }^{2 /}$ Each value represents a mean of three replicate plants with two leave per plant. Mean in the column followed by the same letter are not significantly different according to the LSD test $(\alpha=0.05)$.

\section{DISCUSSION}

In the present work, we show that the application of chitosan and BTH through foliar spray can induce resistance in grapevine against anthracnose caused by $S$. ampelinum. The induction of these resistances was dependent on the concentration of each elicitor, as already observed in a similar comparison carried out in a different pathosystem (Faoro et al., 2008). The most efficient induction was obtained when concentrations of 5 000 ppm for chitosan and 200 ppm for BTH were used. Our study, besides demonstrating for the first time that it is possible to induce resistance against $S$. ampelinum shows that this resistance is associated with salicylic acid and PR proteins synthesis, which are common plant biochemical responses associated to SAR activation
(Sathiyabama et al., 1995; Mandal et al., 2009; Buensanteai et al., 2009; Cortes-Barco et al., 2010; Cohen et al., 2011). Interestingly, we found a major increase in SA accumulation in chitosan and BTH treated grapevine compared to the negative control after inoculation with $S$. ampelinum. The differential expression of the salicylic acid marker after pathogen challenge was similar to the induction of SA and jasmonic acid accumulation in grapevine by $\beta$-aminobutyric acid (BABA), that was potentiated by exposure to a callose formation preparation against Plasmopara viticola, the causal agent of downy mildew (Hamiduzzaman et al., 2005) and it is indicative of plant priming for resistance as defined by different authors (Sticher et al.(1997); Conrath et al. (2006); Trouvelot et al. (2007); Buensanteai et al. (2009) Archana et al. (2011)). 
Table 5. Activity of PPO in leaves of grapevine cultivars Black Queens with or without chitosan and BTH foliar treatment and after challenge inoculation with Sphaceloma ampelinum.

\begin{tabular}{|c|c|c|c|}
\hline \multirow{2}{*}{ Treatment } & \multicolumn{3}{|c|}{ PPO activity ( $\mu \mathrm{mol}$ quinone formed $\mathrm{min}^{-1} \mathrm{mg}^{-1}$ protein) ${ }^{1 /}$} \\
\hline & 0 & 7 days & 14 days \\
\hline CHN 1,000 ppm & $3.061^{\text {ef2/ }}$ & $2.987^{\text {ef }}$ & $8.297^{e}$ \\
\hline CHN 2,500 ppm & $3.170^{f}$ & $2.687^{\text {de }}$ & $7.843^{c}$ \\
\hline CHN 5,000 ppm & $2.514^{\mathrm{C}}$ & $1.757^{\mathrm{b}} \mathrm{c}$ & $7.363^{\mathrm{C}}$ \\
\hline BTH 50 ppm & $2.612^{c}$ & $2.497^{\mathrm{C}} \mathrm{d}$ & $7.953^{\mathrm{de}}$ \\
\hline BTH 100 ppm & $1.403^{\mathrm{a}}$ & $4.217^{g}$ & $10.153^{g}$ \\
\hline BTH 200 ppm & $2.171^{\mathrm{b}}$ & $3.383^{f}$ & $11.227^{\mathrm{h}}$ \\
\hline Control & $2.861^{d}$ & $0.633^{\mathrm{a}}$ & $4.053^{a}$ \\
\hline F-test & ** & ** & ** \\
\hline $\mathrm{CV}(\%)$ & 22.48 & 13.46 & 2.71 \\
\hline
\end{tabular}

${ }^{1 / P P O}$ activity was evaluated at 0 and 7 days after treatment with chitosan and BTH or sterile distilled water (control) and at 7 days after challenging with S. ampelinum strain GB4 (14 days after treatment); ${ }^{2 /}$ Each value represents a mean of three replicate plants with two leave per plant. Mean in the column followed by the same letter are not significantly different according to the LSD test $(\alpha=0.05)$.

Moreover, we found increases in PR proteins and defense enzyme levels in chitosan and BTH-treated plants compared to the non-treated controls, with significant enhancement of these defense compounds being more pronounced in chitosan after pathogen challenging. These results further support the conclusion that chitosan and BTH prime for resistance instead of directly activating it (Aziz et al., 2006; Aziz et al., 2007; Allégre et al., 2009; Dubreuil-Maurizi et al., 2010; Dufour et al., 2012). The significance of priming is that the synthesis of proteins involved in defense occurs only upon pathogen infection, and thus, there are low fitness costs for the plant in the absence of the pathogen (Conrath et al., 2006; Buensanteai et al., 2009; Perazzoli et al., 2008; Legay et al., 2011), as would be expected when treatment with elicitors lead to the direct expression of resistance mechanisms (Heil, 2002; Buensanteai et al., 2009; Körösi et al., 2011).

In conclusion, chitosan and BTH were found to be capable of inducing resistance in grapevine against anthracnose disease and this resistance was associated with the expression of SAR genes. Moreover the activation of SAR biochemical markers, as salicylic acid, PR proteins and defense enzymes, correlated with the resistance degree to anthracnose disease and with disease severity. These findings can have important implications in the use of chitosan and BTH as activeelicitors for integrated plant disease control in vineyard.

\section{ACKNOWLEDGMENTS}

The authors wish to express our special thanks to the Suranaree University of Technology for providing the grant support. Also, this research was partially supported by funds from the Evaluation of Potential and Moon River
Basin Hydropower Development Plan. We also wish to express our special thanks to Plant Pathology Laboratory, Suranaree University of Technology, and to graduate students and research assistant for the technical assistance. Moreover, this work was supported by Suranaree University of Technology and by the Higher Education Research Promotion and National Research University Project of Thailand, Office of the Higher Education Commission.

\section{REFERENCES}

Allégre $\mathrm{M}$, Marie-Claire $\mathrm{H}$, Trouvelot S, Daire X, Pugin A, Wandehenne $D$, Adrian $M$ (2009). Are grapevine stomata involved in the elicitorinduced production against downy mildew. MPMI, 22(8):977-986.

Archana S, Prabakar K, Hubballi M, Valarmathi P, Prakasam V (2011). Defense responses of grapevine to Plasmopara viticola induced by azoxystrobin and Pseudomonas fluorescens. IJSA, 3(1):30-38.

Awadalla OA, Mahamoud GYA (2005). New chitosan derivatives induced resistance to Fusarium wilt disease thought Phytoalexin (Gossypol) production. Sains Malaysiana, 34(2): 141-146.

Aziz A, Trotel-Aziz P, Dhuicq L, Jeandet P, Couderchet M, Vernet G (2006). Chitosan oligomers and copper sulfate induce grapevine defense reactions and resistance to gray mold and downy mildew. Phytopathology 96:1188-1194.

Aziz A, Gautheir A, Bezier A, Poinssot B, Jean-Marie J, Pugin A, Heyraud A, Baillieul $F$ (2007). Elicitor and resistance-inducing activities of $\beta-1,4$ cellodextrins in grapevine, comparison with $\beta$ 1,3glucans and $\alpha-1,4$ oligogalacturonides. J Exp Bot, 58(6): 14631472.

Bradford, M (1976). A rapid and sensitive method for the quantitation of microgram quantities of protein utilizing the principle of protein-dye binding. Anal Biochem,72:248-254.

Buensanteai N, Athinuwat D, Chatnaparat T, Yuen GY, Prathuangwong $S$ (2008). Extracellular proteome of Bacillus amyloliguefaciens KPS46 and its effect on enhanced growth promotion and induced resistance against Bacterial Pustule on soybean. Kasetsart J, 42:1326.

Buensanteai N, Yuen GY, Prathuangwong S (2009). Priming, signaling, and protein production associated with induced resistance by Bacillus amyloliguefaciens KPS46. World J Microbiol Biotechnol, 25:12751286. 
Cohen Y, Rubin EA, Vaknin M (2011). Post infection application of DL3-amino-butyic acid (BABA) induces multiple forms of resistance against Bremia lacticae in lettuce. Eur J Plant Pathol, 130: 13-27.

Conrath U, Beckers GJM, Flors V, Garcı'a-Agustı'n P, Jakab G, Mauch F, Newman M, Pieterse CMJ, Poinssot B, Pozo MJ, Pugin A, Schaffrath U, Ton J, Wendehenne D, Zimmerli L, Mauch-Mani B (2006). Priming: getting ready for battle. MPMI, 19: 1062-1071.

Cortes-Barco AM, Goowin PH, Hsiang I (2010). Comparsion of induced resistance activated by benzothiadiazole, $(2 \mathrm{R}, 3 \mathrm{R})$-butanediol and an isoparaffin mixture against anthracnose of Nicotiana benthamiana. Plant Pathol. 59:643-653.

Dubreuil-Maurizi $C$, Trouvelot $S$, Frettinger $P$, Pugin A, Wendehenne D, Poinssot B (2010). $\beta$-Aminobutyric acid primes an NADPH oxidasedependent reactive oxygen species production during grapevinetriggered immunity. MPMI, 23(8):1012-1021.

Dufour MC, Lambert C, Bouscaut J, Mérillon JM, Corio-Costet MF (2012). Benzothiadiazole-primed defence responses and enhanced differential expression of defence genes in Vitis vinifera infected with biotrophic pathogens Erysiphe necator and Plasmopara viticola. Plant Pathol, 1-13.

Durrant WE, Dong X (2004). Systemic acquired resistance. Annu. Rev. Phytopathol, 42:185-209.

Eikemo H, Stensvand A, Transmo AM (2003). Induce resistance as a possible mean to control of strawberry caused by Phytophthora spp. Plant Dis., 87: 345-350.

El Hadrami A, Adam LR, El Hadrami I, Daayf F (2010). Chitosan in crop protection. Marine Drugs., 8:968-987

Eschen-Lippold L, Altmann S, Rosahl R (2010). DL- $\beta$-aminobutyic acidinduced resistance of potato against Phythopthora infestans requires salicylic acid but not oxylipins. MPMI, 23(5): 585-592.

Faoro F, Maffi D, Cantu D, Iriti M (2008). Chemical-induced resistance against powdery mildew in barley: The effects of chitosan and benzothiadiazole. BioControl, 53: 387-401.

Friedrich L, Lawton K, Ruess W, Masner P, Specker N, Gut-Rella M, Meier B, Dincher S, Staub T, Uknes S, Metraux JP, Kessmann H, Ryals J (1996). A benzothiadiazole derivative induces systemic acquired resistance in tobacco. The Plant Journal, 10: 61-70

Godard FJ, Ziadi S, Monot C, Corre LD, Silué D (1999). Benzothiadiazole (BTH) induces resistance in cauliflower (Brassica oleracea var botrytis) to downy mildew of crucifers caused by Peronospora parasitica. Crop Protec, 18: 397-405.

Godard S, Slacanin I, Viret O Gindro K (2009). Induction of defence mechanisms in grapevine leaves by emodin - and anthraquinone-rich plant extracts and their conferred resistance to downy mildew. PPB, 47: 827-837.

Graham, JH, Myers ME (2011). Soil application of SAR inducers imidacloprid, thiamethoxam, and acibenzolar-S-methyl for citrus canker control in young grapefruit trees. Plant Dis, 95: 725-728.

Hamiduzzaman MM, Jakab G, Barnavon L, Jean-Marc N, Mauch-Mini B (2005). $\quad \beta$-Aminobutyric acid-induced resistance against downy mildew in grapevine acts through the potentiation of callose formation and jasmonic acid signaling. MPMI, 18(8): 819-829.

Hatem B, Wahab AM, Chong J, Bertsch C, Mliki A (2012). Thiamine induced resistance to Plasmopara viticola in grapevine and elicited host-defense responses, including HR like-cell death. PPB, 1-14.

Heil M (2002). Ecological costs of induced resistance. Curr Opin Plant Biol, 5:345-350

Iriti M, Rossoni M, Borgo M, Faoro F (2004). Benzothiadiazole enhances resveratrol and anthocyanin biosynthesis in grapevine, meanwhile improving resistance to Botrytis cinerea. JAFC, 52: 4406-4413.

Iriti $M$ and Faoro $F(2009)$. Chitosan as a MAMP, searching for a PRR. Plant Signaling

and Behaviour, 4: 66-68.

Iriti M, Vitalini S, Di Tommaso G, D'Amico S, Borgo M, Faoro F (2011). New chitosan formulation prevents grapevine powdery mildew infection and improves polyphenol content and free radial scavenging activity of grape and wine. ASVO Inc, 263-269.

Jetiyanon K, Tuzun S, Kloepper JW (1997). Lignification, peroxidase and superoxidase dismutases as early plant defense reactions associated with PGPR-mediated induced systemic resistance. In Plant Growth Promoting Rhizobacteria: Present Status and Future Prospects. Japan, pp. 265-268.

Körösi K, Bán R, Barna B, Virányi F (2011). Biochemical and molecular changes in downy mildew-infected sunflower triggered by resistance inducers. Phytopathology, 159: 471-478.

Kuć J, Richmond S (1997). Aspects of protection of cucumber against Colletotrichum lagenarium by Colletotrichum lagenarium. Phytopathology 67:533-536.

Legay G, Marouf E, Berger D, Neuhaus MJ, Mauch-Mani B, Slaughter RA (2011). Identification of genes expressed during the compatible interaction of grapevine with Plasmopara viticola through suppression subtractive hybridization (SSH). Eur J. Plant Pathol, 129(2): 281-301.

Malamy J, Carr JP, Klessig DF, Raskin I (1990). Salicylic acid: a likely endogenous signal in the resistance response of tobacco to tobacco mosaic virus. Science, 250: 1002-1004.

Mandal S, Mallick N, Mitra A. (2009). Salicylic acid-induced resistance to Fusarium oxysporun f. sp. Lycopersici intomato. PPB, 47: 642-649.

Manjunatha G, Niranjan-Raj S, Prashanth NG, Deeoak S, Amruthesh NK, Shetty SH (2009). Nitri oxide is involved in chitosan-induced systemic resistance in pearl millet against downy mildew disease. Pest Manag. Sci. 65:737-743.

Pan SQ, Ye XS, Kuć J (1991). Association of $\beta-1$,3-glucanase activity and isoform pattern with systemic resistance to blue mould in tobacco induced by stem injection with Peronospora tobanica on leaf inoculated with tobacco mosaic virus. Physiol. Mol. Plant Pathol. 39:25-29.

Perazzoli M, Dagostin S, Ferrai A, Elad Y, Pertot I (2008). Induction of systemic resistance against Plasmopara viticola in grapevine by Trichoderma harzianum and benzothiadaiazole. Biol. Contrl. 47: 228234.

Perazzoli M, Roatti B, Bozza E, Pertot I (2011). Trichoderma harzianum T39 induces resistance against downy mildew by priming for defense without costs for grapevine. Biological Control, 58: 74-82.

Pienpuck K, Choobamroong W, Kueprakone U (1993). Sphaceloma ampelinum of grape scab in Thailand. Thai Agri. Res. J. 11(2): 66 72.

Poolsawat O, Tharapreuksapong A, Jenweerawat S, Wongkeaw S, Thipayapong P (2008). Diversity of Sphaceloma ampelinum, causal pathogen of grape scab in Thailand. Proceed. Intl Workshop Trop. Subtrop. Fruit, 345-353.

Poolsawat O, Tharapreuksapong A, Wongkaew S, Reisch B, Tantasawat $P(2010)$. Genetic diversity and pathogenecity analysis of Sphaceloma ampelinum causing grape anthracnose in Thailand. J. of Phytopathology, 158:837-840.

Raskin I, Turner I, Melander WR (1989). Regulation of heat production in the inflorescences of an Arum lily by endogenous salicylic acid. PNAS. 86: 2214-2218.

Sathiyabama M, Balabramaian R (1995). Chitosan induces resistance component in Arachis hypogaea against leaf rust caused by Puccinia arachidian Spey. Crop Protec, 17(4): 307-313.

Slaughter RA, Hamiduzzaman MM, Gindro K, Jean-Marc N, Mauch-Mini B (2008). Beta -aminobutyric acid-induced resistance in grapevine against downy: involvement of pterostilbene. Eur J Plant Pathol, 122: 185-189.

Sompong M, Wongkaew S, Tantasawat P, Buensanteai N (2012). Morphological, pathogenecity and virulence characterization of Sphaceloma ampelinum the causal agent of grape anthracnose in Thailand. Arf J Microbiol Res, 6(10): 2313-2320.

Sticher L, Mauch-Mani B, Metraux JP (1997). Systemic acquired resistance. Annu Rev Phytopathol, 35: 235-270.

Thipayapong P, Hunt MD, Steffens JC (1995). Systemic wound induction of potato (Solanum tuberosum) polyphenol oxidase. Phytochem. 40: 673-676.

Trouvelot S, Varier LA, Allégre M, Baillieul F, Arnould C, GianinazziPearson V, Klarzynki O, Joubert MJ, Pugin A, Daire X (2007). A $\beta-1,3$ Glucan sulfate induces resistance in grapevine against Plasmopara viticola through priming of defense responses, including HR-like cell death. MPMI, 21(2):232-243.

Vallad GE, Goodman RM (2004). Systemic acquired resistance and induced systemic resistance in conventional agriculture. Crop Sci, 44:1920-1934.

Verhagen MWB, Trotel-Aziz P, Couderchet M, Höfte M, Aziz A (2010). 
Pseudomonas spp.-induced systemic resistance to Botrytis cinerea is associated with induction and priming of defence responses in grapevine. J. Exp. Bot. 61(1):249-260.

Verhagen B, Trotel-Aziz P, Jeandet P, Baillieul F, Aziz A (2011). Improved resistance against Botrytis cinerea by grapevine-associated bacteria that induce a prime oxidative burst and phytoalexin production. Phytopathology 101:768-777.
Vidal S, Leon IP, Denecke J, Palva ET (1997). Salicylic acid and plant pathogen Erwinia caratovora induce defense genes via antagonistic pathway. Plant J. 11:115-123.

Wongkaew S, Boonkerd N (2010). Integrated Management of Grape Diseases. Suranaree University of Technology Research Report. 